\title{
Whey protein supplement as a source of microencapsulated PUFA-rich vegetable oils
}

\author{
Valquíria Maeda Rojas ${ }^{a}$, Alexandre Guimarães Inácio a, Isabel Patricia Martins Fernandes c, d, \\ Fernanda Vitória Leimann ${ }^{\mathrm{a}, \mathrm{c}, \mathrm{d}}$, Angela Maria Gozzo ${ }^{\mathrm{b}}$, Renata Hernandez Barros Fuchs ${ }^{\mathrm{b}}$, \\ Maria Filomena Filipe Barreiro ${ }^{\text {c, }}$, Lillian Barros ${ }^{\mathrm{d}}$, Isabel C.F.R. Ferreira ${ }^{\mathrm{d}, *}$, \\ Ailey Aparecida Coelho Tanamati ${ }^{\text {a }}$, Odinei Hess Gonçalves ${ }^{\text {a,c, } d}$ \\ ${ }^{a}$ Post-Graduation Program of Food Technology, Federal University of Technology - Paraná, 87301-899, Campo Mourão, Paraná, Brazil \\ ${ }^{\mathrm{b}}$ Food Department, Federal University of Technology - Paraná, 87301-899, Campo Mourão, Paraná, Brazil \\ ${ }^{\mathrm{c}}$ Laboratory of Separation and Reaction Engineering - Laboratory of Catalysis and Materials (LSRE-LCM), Polytechnic Institute of Bragança, Campus Santa Apolónia, \\ 5301-857, Bragança, Portugal \\ ${ }^{\mathrm{d}}$ Centro de Investigação de Montanha (CIMO), Instituto Politécnico de Bragança, Campus Santa Apolónia, 5300-253, Bragança, Portugal
}

\section{A R T I C L E I N F O}

\section{Keywords:}

Polyunsaturated fatty acids

Encapsulation

Whey protein supplement

Vegetable oil

Coffea arabica

Juglans regia

\begin{abstract}
A B S T R A C T
Whey protein supplements (WPS) intake has been increasing worldwide as they are mainly used to improve overall athletic performance. Adding other bioactives such as polyunsaturated fatty acids (PUFA) may be an alternative to help fulfill nutritional needs. Microencapsulation is able to protect PUFA-rich oils from oxidation, but important aspects of particle production and their influence on food properties must be evaluated. This study aimed to develop WPS with microencapsulated green coffee and walnut oils using stearic acid as a wall material. Oxidative stability (differential scanning calorimetry) of the oils increased (from $82 \pm 4$ to $110 \pm 10 \mathrm{~kJ} \mathrm{~mol}^{-1}$ for green coffee oil and from $90 \pm 5$ to $149 \pm 1 \mathrm{~kJ} \mathrm{~mol}^{-1}$ for walnut oil) after encapsulation and WPS rheological properties were not affected by the microcapsules $(\mathrm{p}<0.05)$. Sensory analysis of the supplement containing microencapsulated green coffee oil showed a lower sensory preference than the blank sample, but no difference was found with the blank sample in the case of walnut oil $(\mathrm{p}<0.05)$. The encapsulation strategy used to produce an enriched WPS was efficient in protecting the oils from oxidative degradation.
\end{abstract}

\section{Introduction}

The combination of nutritional supplements with physical exercise is often seen by fitness enthusiasts and professional athletes as an approach to improve the quality of life and to achieve a healthier lifestyle. The ingestion of supplements has been increasing and whey protein-based products are often used by consumers. Whey protein is the soluble protein fraction of milk serum that is obtained during cheese and casein production and its biological properties have been described (Garrido et al., 2016). Milk proteins and particularly whey are important for human nutrition due to the presence of some natural bioactive substances (Groziak \& Miller, 2000). Their enrichment with other bioactive molecules such as polyunsaturated fatty acids (PUFA) might be beneficial and is a potentially important strategy to follow.

Edible vegetable oils with PUFA are important for human nutrition including concerns related to addressing the imbalanced intake of saturated and unsaturated fatty acids, particularly in western diets. Green coffee (Coffea arabica) oil is $\sim 75 \%$ triglycerides and contains caffeine, sterols, terpenes and tocopherols. It is high in PUFA and monounsaturated FA (MUFA) and also volatile compounds (Getachew \& Chun, 2016). Coffee is one of the most important global commodities (Getachew \& Chun, 2016) with an annual production of 8 million tonnes/yr (Bresciani et al., 2014). Walnuts (Juglans regia) contain $\sim 60 \%$ lipids (Martínez et al., 2011), and $\sim 75 \%$ of them are PUFA. The oil is also valuable due to the presence of tocopherols, polyphenols and phytosterols (Calvo et al., 2011).

In comparison to saturated oils, PUFA rich oils are more susceptible to oxidation, which may lead to undesirable sensory characteristics and thus impact on the overall quality (Mexis et al., 2009). Oxidative processes are complex and may be influenced by the presence of free fatty

\footnotetext{
* Corresponding author.

E-mail address: iferreira@ipb.pt (I.C.F.R. Ferreira).
} 
acids (FFA), metals and other components such as pigments (Ixtaina et al., 2011). Since oxidative degradation is an exothermic process, differential scanning calorimetry (DSC) and thermogravimetric analysis (TGA) techniques can be used to study the thermal behavior of foodstuff, taking into account that the associated oxidative processes are complex and are different upon heating with non-isothermal conditions (Ciprioti et al., 2017).

The stability of various vegetable oils, including canola, soy and corn (Adhvaryu et al., 2000), chia seeds and linseed oils (Grampone et al., 2013) and linoleic acid (Ulkowski et al., 2005) have been evaluated using thermal methods. DSC data can be analyzed using an isoconversional method such as the one of Ozawa, Flynn and Wall (OFW) (Flynn \& Wall, 1966; Ozawa, 1970) to determine the activation energy of the oxidation reaction. Vegetables oils have been analyzed using this approach assuming that the oxidation reaction follows pseudo first-order kinetics when oxygen is in excess. A constant conversion rate is assumed for every onset oxidation temperature at different heating rates (Ostrowska-Ligeza et al., 2010).

The protection of edible oils against oxidative degradation can be accomplished through encapsulation techniques (Inácio et al., 2018) and hot homogenization provides a reliable way to incorporate liquid oils into solid lipid matrices. Using this method, solid lipids or waxes form a physical barrier that protects such oils from the atmospheric oxygen and also hinders heat transfer. Hot homogenization has been applied to encapsulate a range of active substances to protect against chemical degradation, and migration to food and volatilization, (Đorđević et al., 2015). It was applied to produce microparticles containing chia seeds (Salvia hispanica L.) oil, pumpkin (Cucurbita maxima) oil and baru (Dipteryx alata) oil (Rojas et al., 2019). DSC thermograms showed oil stability increased by comparing the activation energy of the oxidation reaction.

The incorporation of PUFA-rich oil-loaded microparticles in whey protein supplement might provide an ingredient that would improve foodstuffs. It is of particular importance to determine the impact on sensory properties of adding the microcapsules to the whey protein product. Therefore, the objective of this study was to microencapsulate green coffee oil and walnut oil using stearic acid as a wall material and to add the microparticles into commercial whey protein supplement. In addition to the microencapsulation process to avoid oil oxidation, the whey protein supplement was characterized using rheology, colorimetry and evaluated using sensory tests.

\section{Materials and methods}

\subsection{Materials}

Commercial whey protein supplement was acquired in the local market (Whey Protein 5w Health Time brand, São Paulo, Brazil, which is composed of whey protein concentrate, $80.0 \%$ crude proteins, $1.0 \%$ total lipids, $5.0 \%$ carbohydrates and $3.3 \mathrm{kcal} \mathrm{g}^{-1}$ according to the manufacturer). Green coffee oil and walnut oil (without added antioxidants) were acquired from Veris do Brasil Co. (São Paulo, Brazil) and keep protected from light at $-10{ }^{\circ} \mathrm{C}$ until use (maximum of $3 \mathrm{wk}$ ). Stearic acid (Sigma-Aldrich Co., St. Louis, MO, USA, analytical grade), sodium caseinate (Sigma-Aldrich, analytical grade) and distilled water were used as the wall material, stabilizer and continuous medium, respectively, in the microencapsulation process. Methyl tricosanoate (23:0 Me, Sigma-Aldrich, chromatographic standard, $0.3 \mathrm{mg}$ ), $2: 1 \mathrm{v} / \mathrm{v}$ ether:absolute alcohol (Vetec Co., São Paulo, Brazil, analytical grade) solution, 0.01 mol.L $\mathrm{L}^{-1}$ sodium hydroxide solution (Dinâmica Co., São Paulo, Brazil, analytical grade), isooctane (Dinâmica, chromatographic grade), 0.5 mol. $\mathrm{L}^{-1}$ methanolic sodium hydroxide solution, saturated sodium chlorate solution and potassium bromide (Sigma-Aldrich, chromatographic standard) were used. FAME mix (Supelco 37 Component FAME mix, Sigma-Aldrich) was used as the chromatograph standard. Synthetic air (Air Liquid Co., Maringá, Paraná, Brazil, $79 \% \mathrm{~N}_{2}$,
$21 \% \mathrm{O}_{2}$ ) and gaseous nitrogen were used in the thermal analyses.

\subsection{Microparticles production}

The procedure described by Inácio et al. (2018) was used to produce the microparticles. Briefly, sodium caseinate $(0.275 \mathrm{~g})$ was dissolved in $250.0 \mathrm{~g}$ distilled water and heated to $75{ }^{\circ} \mathrm{C}$ with gentle stirring. Meanwhile, $16.75 \mathrm{~g}$ stearic acid was melted at $75{ }^{\circ} \mathrm{C}$ in a jacketed glass flask connected to a thermostatic bath. Thereafter, the oils (green coffee or walnut, $8.25 \mathrm{~g}$ ) were added with gentle stirring. After $1 \mathrm{~min}$, the caseinate aqueous solution was added and the system stirred at 8600 rpm for 5 min (Ultraturrax IKA- T25-S25N10G, IKA Werke GmbH \& Co. KG, Staufen, Germany). The dispersion was quickly quenched with an ice bath to give solid microparticles. The microparticles were lyophilized (Liotop L101, Liobras Co., Sao Paulo, Brazil) and stored at $-10{ }^{\circ} \mathrm{C}$ protected from light for a maximum of 10 days. Blank microparticles were obtained following the same procedure but without oil addition.

\subsection{Oils and microparticles characterization}

Trans-esterification was carried out in triplicate as described by Barros et al. (2013), using methyl tricosanoate as an internal standard at $1.0 \mathrm{mg} . \mathrm{L}^{-1}$ in isooctane. In a screw-cap tube with a screw-cap, $300 \mu \mathrm{L}$ internal standard were added. After evaporation of the solvent under the flow of nitrogen gas, $20 \mathrm{mg}$ oil was added. Then, $4.0 \mathrm{~mL} \mathrm{NaOH} 0.50 \mathrm{~mol}$ $\mathrm{L}^{-1}$ in methanol was added and vigorously agitated for $30 \mathrm{~s}$. The mixture was heated in a bath at $100{ }^{\circ} \mathrm{C}$ for $5 \mathrm{~min}$ and cooled to $25{ }^{\circ} \mathrm{C} .5 \mathrm{~mL}$ esterifying reagent were added (mixture of $2.0 \mathrm{~g}$ ammonia chloride, $60.0 \mathrm{~mL}$ methanol, and $3.0 \mathrm{~mL}$ sulfuric acid) followed by saturated $\mathrm{NaCl}$ solution $(0.5 \mathrm{~mL})$ and isoctane $(2 \mathrm{~mL})$. The esterified sample was left at $10{ }^{\circ} \mathrm{C}$ for better phase separation. The supernatant containing the methyl fatty esters was collected and kept at $-18^{\circ} \mathrm{C}$ for a maximum of 1 $\mathrm{h}$ for the gas chromatograph analysis. Fatty acids (FA) profile was obtained using gas chromatography coupled to a flame ionization detection (GC 1000, GC-FID, Dani Co., Milan, Italy). FA identification was done by comparing the relative retention time of the FAME standards with the samples. Results were expressed as relative percentage of each FA.

Tocopherols were determined following a procedure described by Barros et al. (2013) using a HPLC system (Smartline system 1000, Knauer Co., Berlin, Germany) coupled to a fluorescence detector (excitation at $290 \mathrm{~nm}$ and emission at $330 \mathrm{~nm}$; FP-2020; Jasco, Easton, WA, USA). BHT solution in hexane (Fisher Scientific, Lisbon, Portugal, $10 \mathrm{mg}$ $\mathrm{mL}^{-1}, 100 \mu \mathrm{L}$ ) and the internal standard solution in hexane (racemic tocol; $50 \mu \mathrm{g} \mathrm{mL}-1,400 \mu \mathrm{L}$ ) were added to the sample prior to the extraction procedure. The samples $(\sim 500 \mathrm{mg})$ were homogenized with methanol $(4 \mathrm{~mL})$ for $1 \mathrm{~min}$ and hexane $(4 \mathrm{~mL})$ was added. Saturated $\mathrm{NaCl}$ aqueous solution $(2 \mathrm{~mL}$ ) was added, the mixture was homogenized in the Ultraturrax $(1 \mathrm{~min})$, centrifuged $(5 \mathrm{~min}, 4000 \times \mathrm{g}$ ) and the clear upper layer was transferred to a vial. The sample was re-extracted twice with hexane. The combined extracts were taken to dryness under a nitrogen stream, redissolved in $2 \mathrm{~mL}$ of $\mathrm{n}$-hexane, dehydrated with anhydrous sodium sulphate, filtered through $0.2 \mu \mathrm{m}$ nylon filters (Whatman, Maidstone, UK), transferred into a dark injection vial and analyzed using the HPLC system described above. The chromatographic separation was achieved with a normal-phase column (Polyamide II 250 $\mathrm{mm} \times 4.6 \mathrm{~mm}$ i.d., YMC, Waters) at $30^{\circ} \mathrm{C}$. The mobile phase used was a mixture of n-hexane and ethyl acetate (HPLC grade, Fisher Scientific, Lisbon, Portugal, 70:30 v/v) at $1 \mathrm{~mL} \mathrm{~min}^{-1}$ and the injection volume was $20 \mu \mathrm{L}$. Quantification was done using commercial standards of tocopherols ( $\alpha$-, $\beta$-, $\gamma$-, and $\delta$-isoforms, Matreya, Pleasant Gap, PA, USA), by applying the internal standard methodology. The results were expressed in $\mathrm{mg} / 100 \mathrm{~g}$ oil.

Fourier transform infrared spectroscopy (FTIR, IR Affinity-1, Shimadzu Inc., Tokyo, Japan) analysis was carried out at $2 \mathrm{~cm}^{-1}$ resolution by combining 32 scans in the spectral range of 4000 to $400 \mathrm{~cm}^{-1}$ at 0.2 
$\mathrm{cm} \mathrm{s}^{-1}$. Sample ( $2 \mathrm{~g}$ ) was mixed with $200 \mathrm{mg}$ of potassium bromide and pelletized under pressure at $10 \mathrm{~kg}_{\mathrm{f}} \mathrm{cm}^{-2}$.

DSC (DSC-4000, PerkinElmer Inc., Waltham, MA, USA) with a $\mathrm{N}_{2}$ flow rate of $50 \mathrm{~mL} \mathrm{~min}^{-1} \mathrm{~N}_{2}$ and heating rate of $20^{\circ} \mathrm{C} \mathrm{min}{ }^{-1}$ from 0 to $150{ }^{\circ} \mathrm{C}$ was used to evaluate microparticles thermal behavior. An amount of $\sim 10 \mathrm{mg}$ of each sample was put in a closed aluminum sample holder.

The parameters $D_{10}, D_{50}$ and $D_{90}$, corresponding to the size of 10,50 and $90 \%$ of the microparticles, respectively, were calculated from the volumetric cumulative sizes distribution (Mastersizer 3000, Malvern Inc., Malvern, Worcestershire, UK) using water as the dispersant. The span was calculated using Equation (1).

$\operatorname{Span}(-)=\frac{D_{90}-D_{10}}{D_{50}}$

Scanning electron microscopy (SEM) images of gold coated (Quorum Q150R, Quorum Technologies Inc., Laughton, UK) microparticles were obtained using a EVO MA 15 SEM (Carl Zeiss Inc., Oberkochen, Germany) coupled with a backscattering detector, acceleration voltage of $15 \mathrm{kV}$ and $500 \times$ magnification.

Encapsulation efficiency was determined using the methodology described by Inácio et al. (2018). Lyophilized microparticles (20-30 mg) were esterified as described earlier to determine the total amount of FA ([FA $]_{\text {total }}$ ) using gas chromatography. An aliquot of the microparticles dispersion was washed with 100\% ethanol and filtered (paper filter with $3 \mu \mathrm{m}$ porosity, Dinâmica) to remove the free oil, and then also esterified to determine the amount of FA entrapped inside the microparticles

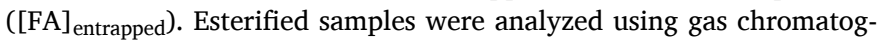
raphy as described above. Encapsulation efficiency was calculated using Equation (2) for linoleic acid and $\alpha$-linolenic acid because they were the most abundant PUFA in the oils.

$E E(\%)=\frac{[F A]_{\text {entrapped }}}{[F A]_{\text {total }}} .100$

TGA was carried out using a thermobalance (TGA-50, Shimadzu Inc.). Samples ( $\sim 4 \mathrm{mg})$ were put inside aluminum sample holders and heated from 30 to $650{ }^{\circ} \mathrm{C}$ at $10{ }^{\circ} \mathrm{C} \mathrm{min}{ }^{-1}$ under a nitrogen atmosphere $\left(150 \mathrm{~mL} \mathrm{~min}^{-1}\right)$ to determine transition temperatures and enthalpy.

Oxidative stability was determined using DSC as described elsewhere (Rojas et al., 2019) using zinc (429.75 K and $107 \mathrm{~J} \mathrm{~g}^{-1}$ ) and indium standards (692.68 $\mathrm{K}$ and $28.5 \mathrm{~J} \mathrm{~g}^{-1}$ ) for calibration. Briefly, oil or lyophilized microparticles were put in open aluminum holders under a synthetic air flux at $100 \mathrm{~mL} \mathrm{~min}^{-1}$ from 0 to $440{ }^{\circ} \mathrm{C}$ using different heating rates $\left(1,5,10\right.$ and $\left.20^{\circ} \mathrm{C} \mathrm{min}{ }^{-1}\right)$. The activation energy $\left(E_{a}, k J\right.$ $\mathrm{mol}^{-1}$ ) involved in the lipid oxidation reaction was calculated using Equations (3) and (4) (Flynn \& Wall, 1966; Inácio et al., 2018; Ostrowska-Ligeza et al., 2010; Ozawa, 1970) using MATLAB R2008b software (The MathWorks, Inc., CA, USA).

$\log \beta=a T^{-1}+b$

$E_{a}=-2,19 R \frac{d \log \beta}{d T^{-1}}$

In these equations, $\beta$ is the heating rate $\left({ }^{\circ} \mathrm{C} \min ^{-1}\right)$, "a" and " $\mathrm{b}$ " are the slope and intercept of the adjusted curve, respectively, and $\mathrm{R}$ is the universal gas constant $\left(8.3143 \mathrm{~J} \mathrm{~mol}^{-1} \mathrm{~K}^{-1}\right)$. The oxidation onset temperature $\left(\mathrm{T},{ }^{\circ} \mathrm{C}\right)$ was found by extrapolation considering the tangent line (leading edge) and the thermogram baseline (Inácio et al., 2018; Ostrowska-Ligeza et al., 2010). The experimental procedure was carried out in duplicate for each heating rate.

\subsection{Formulation of the whey protein supplement with the oil-loaded microparticles}

Oil-loaded microparticles were added to the commercial whey protein supplement at 2.5, 5.0 and $7.5 \% \mathrm{w} / \mathrm{w}$ concentration. Then, $25 \mathrm{~g}$ of the whey supplement were added to $125 \mathrm{~mL}$ water and mixed for $5 \mathrm{~min}$. A colorimeter (CR-400, Konica Minolta Inc., Tokyo, Japan) was used to determine the parameters $\mathrm{L}^{*}$ (luminosity), $\mathrm{a}^{*}$ (from green to red) and $\mathrm{b}^{*}$ (from blue to yellow) at the surface of the solution (Altunkaya et al., 2013). Saturation (chroma, $C^{*}$ ) and tonality angle (hue angle, $h^{\circ}$ ) were calculated using Equations (5) and (6), respectively (Lancaster \& Lister, 1997; Lemes et al., 2017). Color was analyzed in duplicate with three measurements for each experimental condition.

$C^{*}=\sqrt{a^{*^{2}}+b^{*^{2}}}$

$h^{\circ}=\tan ^{-1}\left(\frac{b^{*}}{a^{*}}\right)$

Rheological measurements (DV-III and spindle SC431, Brookfield Inc, Middleboro, MA, USA) were carried out in duplicate at a spindle speed varying from zero to $100 \mathrm{rpm}$ at 25 and $37^{\circ} \mathrm{C}$ (approximate room temperature and the average human body temperature, respectively). The parameters of the Bingham, Casson and Herschel-Bulkley models were evaluated using Equations (7)-(9), respectively, where $\sigma$ is the shear stress (Pa), $\sigma_{0}$ the yield stress (Pa), $\eta_{a}$ the limiting viscosity (Pa.s), $\dot{\gamma}$ the shear rate $\left(\mathrm{s}^{-1}\right), k_{c}$ the viscosity at infinite shear rate (Pa.s), $k$ the consistency index $\left(\mathrm{Pa} . \mathrm{s}^{\mathrm{n}}\right)$, and $n$ the flow behavior index (dimensionless) (Chivero et al., 2016; Tabilo-Munizaga \& Barbosa-Cánovas, 2005).

$\sigma=\sigma_{0}+\eta_{a} \cdot \dot{\gamma}$

$\sigma^{0,5}=\sigma_{0}^{0,5}+k_{c} \cdot \dot{\gamma}^{0,5}$

$\sigma=\sigma_{0}+k \cdot \dot{\gamma}^{n}$

Instituto Adolfo Lutz (2008) methodologies were applied to determine crude protein, ash, total lipids, moisture and energy content of the whey protein supplement (carbohydrates were calculated by difference). The moisture content was determined gravimetrically by heating the sample in porcelain crucibles in an oven $\left(105{ }^{\circ} \mathrm{C}\right)$ until constant weight was achieved. The ash content was determined with the dried material, using a muffle furnace at $600{ }^{\circ} \mathrm{C}$, where the crucibles were heated until constant weight was achieved and the ash content determined gravimetrically. Total lipids were extracted with a mixture of chloroform:methanol; water at 2:2:1.8 v/v/v and the total lipids content was determined gravimetrically with Soxhlet equipment. Crude protein contents were determined using the semi-micro Kjeldahl method (TE 0363, Tecnal Inc., Piracicaba, São Paulo, Brazil) in which total nitrogen was determined and the factor 6.25 was used for the conversion to total crude protein.

Sensory evaluation was carried out in accordance with the Brazilian regulations with the protocol number 2.341.697 (approved by the Ethics Committee for Research of the Federal University of Technology - Paraná UTFPR on October 10, 2017). The test was applied at the university's Sensory Analysis Laboratory in individual cubicles without the possibility of communication between the assessors. Tests were carried out under white fluorescent lighting (6 W, Taschibra, São Paulo, Brazil) at a controlled ambient temperature of $23^{\circ} \mathrm{C}$.

Two ranking preference tests (ABNT, 2015) were done to evaluate the impact of the addition of green coffee and walnut oil microparticles on whey protein supplement. Samples without addition of particles were served together with the enriched samples to have their preference evaluated by 60 untrained assessors ( $56 \%$ women and $44 \%$ men), aged between 19 and 48 years old, students and university employees, habitual consumers of protein supplements. Thus, in each test the assessors received three coded samples, served in randomized and balanced order, along with a glass of mineral water and an evaluation form. The assessors were asked to rinse with water both before they began testing and between samples, taste the samples from left to right and order them, from the less preferred to the most preferred sample (Fuchs et al., 2013). 
Table 1

Composition of FA (\%w/w) and of tocopherols (mg/100 g oil) of green coffee and walnut oils.

\begin{tabular}{|c|c|c|}
\hline \multirow[t]{2}{*}{ FA } & Green Coffee & Walnut \\
\hline & \multicolumn{2}{|c|}{ Content in \%w/w } \\
\hline 16:0 (Palmitic acid) & $31.5 \pm 0.3$ & $5.66 \pm 0.03$ \\
\hline 16:1 (Palmitoleic acid) & $0.24 \pm 0.01$ & $0.07 \pm 0.01$ \\
\hline 17:0 (Heptadecanoic acid) & $0.24 \pm 0.01$ & $0.05 \pm 0.01$ \\
\hline 18:0 (Stearic acid) & $7.31 \pm 0.04$ & $2.36 \pm 0.01$ \\
\hline 18:1n-9 (Oleic acid) & $8.4 \pm 0.1$ & $12.3 \pm 0.1$ \\
\hline 18:2n-6 (Linoleic acid) & $46.0 \pm 0.1$ & $59.5 \pm 0.1$ \\
\hline 18:3n-3 ( $\alpha$-Linolenic acid) & $2.17 \pm 0.01$ & $19.6 \pm 0.1$ \\
\hline 20:0 (Arachidic acid) & $2.65 \pm 0.03$ & $0.09 \pm 0.01$ \\
\hline 20:1 (Eicosenoic acid) & $0.35 \pm 0.01$ & $0.15 \pm 0.01$ \\
\hline SFA (\%) & $41.7 \pm 0.2$ & $8.16 \pm 0.02$ \\
\hline MUFA (\%) & $9.0 \pm 0.1$ & $12.9 \pm 0.01$ \\
\hline PUFA (\%) & $48.2 \pm 0.1$ & $79.1 \pm 0.1$ \\
\hline PUFA:SFA & 1.16 & 9.58 \\
\hline$n-6: n-3$ & 21.2 & 3.03 \\
\hline Tocopherols & \multicolumn{2}{|c|}{ Concentration in $\mathrm{mg} / 100 \mathrm{~g}$ oil } \\
\hline$\alpha$-Tocopherol & $0.75 \pm 0.05$ & nd \\
\hline$\beta$-Tocopherol & $12.6 \pm 0.1$ & nd \\
\hline$\gamma$-Tocopherol & nd & $3.4 \pm 0.1$ \\
\hline$\delta$-Tocopherol & nd & $2.4 \pm 0.1$ \\
\hline Total Tocopherols & $13.4 \pm 0.1$ & $5.8 \pm 0.2$ \\
\hline
\end{tabular}

SFA: Saturated FA; MUFA: Monounsaturated FA; PUFA: Polyunsaturated FA.

\subsection{Statistical analysis}

Color parameters for each formulation were compared using Tukey test with 5\% significance using Statistica 13.3 software (Tibco Software Inc., Palo Alto, CA, USA). For the sensory analysis, results were analyzed using the Friedman Test $(\mathrm{p}<0.05)$. The curves that showed similar rheological parameters indicating the same rheological behavior had their viscosity compared using the Tukey test with $5 \%$ significance, seeking to verify that each rheological curve did not show any significant difference with each other separately.

\section{Results and discussion}

\subsection{Oil characterization}

FA composition of green coffee oil and walnut oil are shown in Table 1 (retention times and identification are shown in Fig. S1, Supplementary Material).

Linoleic acid and $\alpha$-linolenic acid were the most abundant FA in walnut oil while the predominant FA in green coffee oil were linoleic and palmitic acids. Values are consistent with those reported in the literature (Bertrand et al., 2008; Budryn et al., 2012). For walnut oil, values of 11.9, 63.2 and 14.6\% (Calvo et al., 2011) and 17.6, 54.1 and $15.0 \%$ (Christopoulos \& Tsantili, 2015) were reported for linolenic, linoleic and oleic acids, respectively. PUFA content was considerably higher in both oils meaning that these oils are prone to react with oxygen and undergo degradation. While green coffee showed the presence of $\alpha$ and $\beta$-tocopherols (no $\gamma$ - and $\delta$-tocopherols were detected) and a higher concentration of total tocopherols, walnut oil showed $\gamma$ - and $\delta$-tocopherol (no $\alpha$ - and $\beta$-tocopherols were detected) and a lower amount of total tocopherols. The prevalence of these two isoforms in green coffee oil (González et al., 2001) and walnut oil (Uzunova et al., 2015) have been previously reported.

\subsection{Microparticles characterization}

Encapsulation efficiency (\%) for linoleic acid and $\alpha$-linolenic acid, melting enthalpy $(\Delta \mathrm{H})$ and transition temperatures (DSC curves are included in Supplementary Material, Fig. S2) and particle sizes $\left(D_{10}, D_{50}\right.$ and $\mathrm{D}_{90}$ ) are shown in Table 2. Fig. 1 shows SEM images of the oil-loaded
Table 2

Encapsulation efficiency of linoleic acid and $\alpha$-linolenic acid, microparticles particle size, melting enthalpy and melting temperature for the produced microparticles.

\begin{tabular}{|c|c|c|c|}
\hline & & \multicolumn{2}{|c|}{$\begin{array}{l}\text { Oil-loaded } \\
\text { microparticles }\end{array}$} \\
\hline & & $\begin{array}{l}\text { Green } \\
\text { coffee }\end{array}$ & Walnut \\
\hline \multirow{2}{*}{$\begin{array}{l}\text { Encapsulation efficiency } \\
\text { (\%) }\end{array}$} & 18:2n6 (linoleic acid) & $94 \pm 1$ & $92 \pm 3$ \\
\hline & $\begin{array}{l}\text { 18:3n3 ( } \alpha \text {-linolenic } \\
\text { acid) }\end{array}$ & $103 \pm 1$ & $92 \pm 3$ \\
\hline $\mathrm{D}_{10}(\mu \mathrm{m})$ & & $8.3 \pm 0.9$ & $5.8 \pm 0.1$ \\
\hline $\mathrm{D}_{50}(\mu \mathrm{m})$ & & $39 \pm 3$ & $32 \pm 1$ \\
\hline $\mathrm{D}_{90}(\mu \mathrm{m})$ & & $86 \pm 5$ & $82 \pm 2$ \\
\hline Span & & 2.0 & 2.4 \\
\hline$\Delta \mathrm{H}\left(\mathrm{J} . \mathrm{g}^{-1}\right)$ & & $190 \pm 10$ & $170 \pm 20$ \\
\hline $\mathbf{T}\left({ }^{\circ} \mathbf{C}\right)$ & & $73 \pm 2$ & $74 \pm 6$ \\
\hline
\end{tabular}

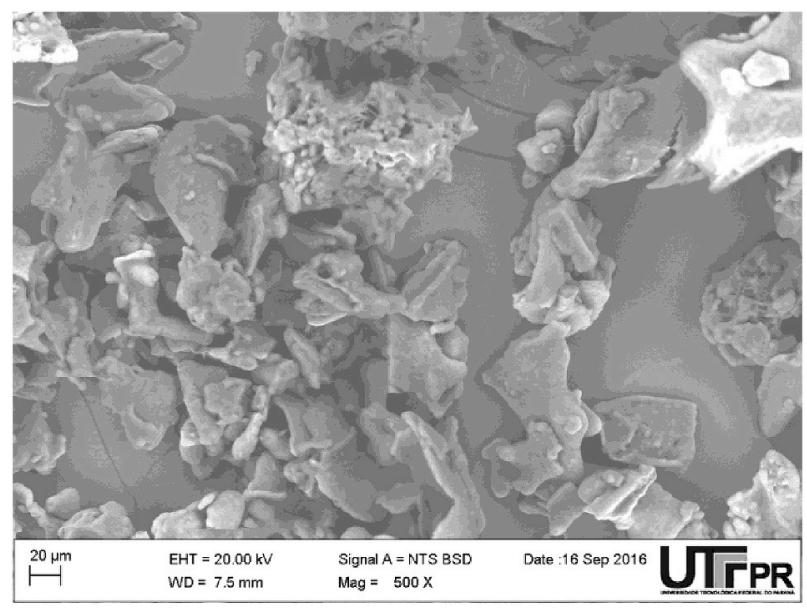

(a)

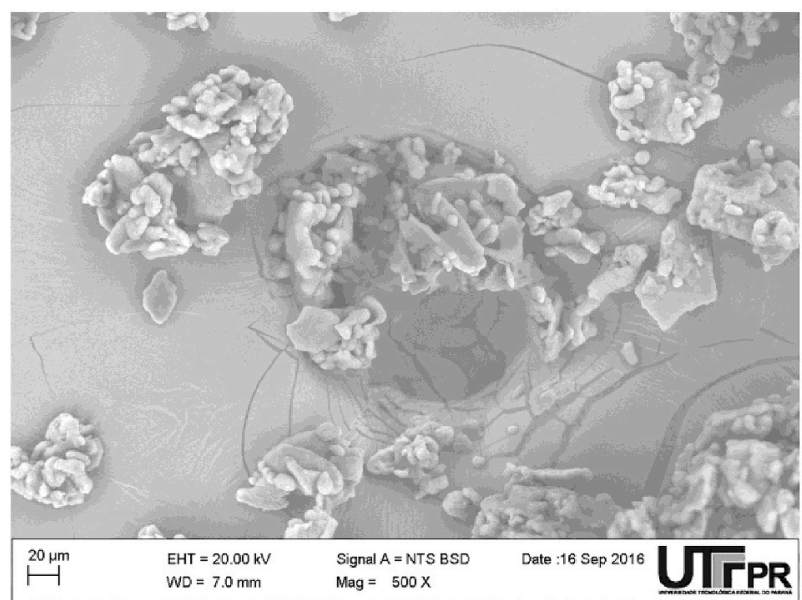

(b)

Fig. 1. Scanning electron microscopy of the oil-loaded microparticles $(500 \times)$. (a) Green coffee oil-loaded microparticles. (b) Walnut oil-loaded microparticles.

microparticles. Infrared spectra for oils and oil-loaded microparticles are shown in Fig. S3 (Supplementary Material).

An encapsulation efficiency $>100 \%$ was found for $\alpha$-linolenic acid possibly due to the low amount of this FA in green coffee oil. Overall, encapsulation efficiency showed high values due to the affinity between 


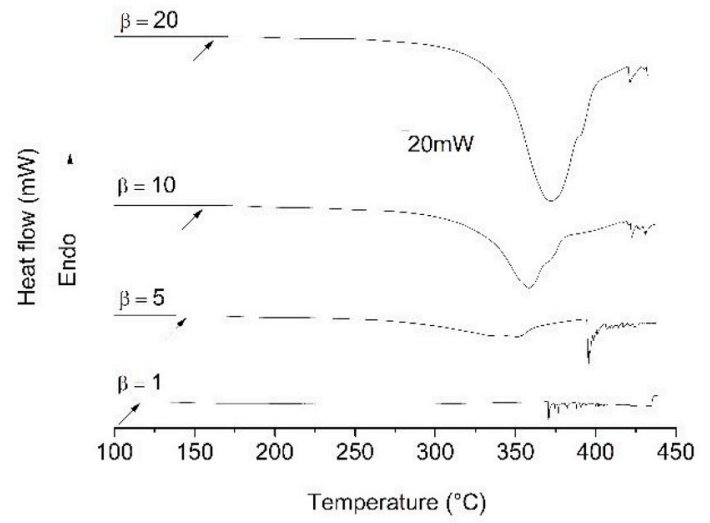

(a)

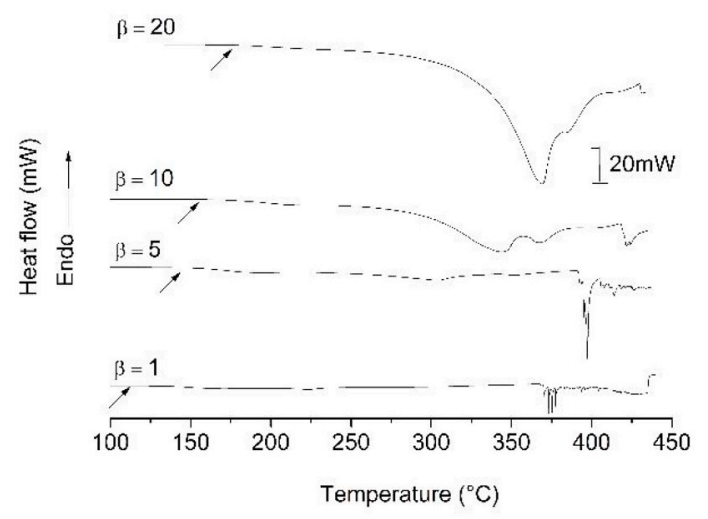

(c)

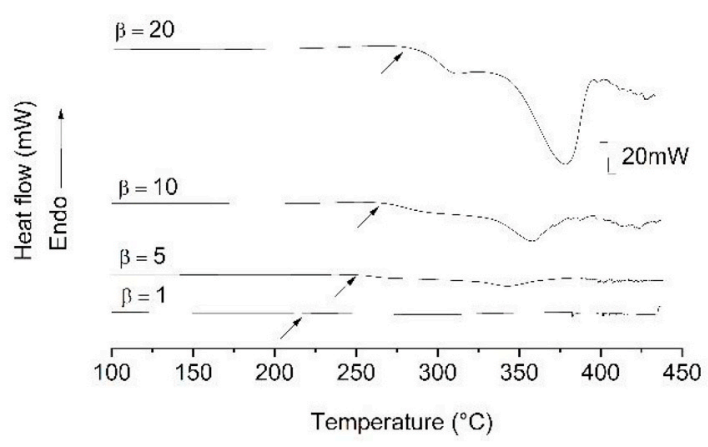

(b)

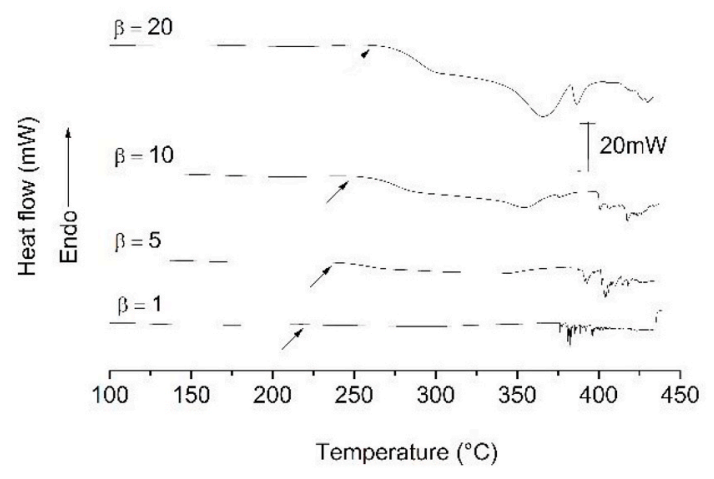

(d)

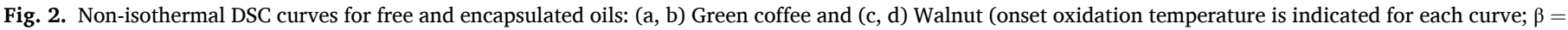
heating rate in ${ }^{\circ} \mathrm{C} \mathrm{min}^{-1}$ ). (a) Green coffee oil. (b) Green coffee-oil loaded microparticles. (c) Walnut oil. (d) Walnut oil-loaded microparticles.

the oils and the encapsulant matrix (stearic acid). This was also observed for spearmint essential oil (Ciftci \& Temelli, 2016) and vitamin E (Albertini et al., 2008). High encapsulation efficiencies were reported for chia seeds oil, pumpkin seeds oil and baru oil using stearic acid as the encapsulant (Rojas et al., 2019). Particle shapes (Fig. 1) were irregular and most of the particles showed sizes $<86 \mu \mathrm{m}$ which may be satisfactory in the case of encapsulated food additives because larger particles could impact acceptance.

The melting enthalpy and the melting temperature for particles obtained using the same experimental conditions, but without oil (blank microparticles), were reported with values of $249 \mathrm{~J} \mathrm{~g}^{-1}$ and $76.4{ }^{\circ} \mathrm{C}$, respectively (Rojas et al., 2019). Although the melting temperature did not change due to the presence of the oils, the melting enthalpy showed a sharp decrease of $\sim 70 \%$, which is in accordance with the amount of oil used and the encapsulation efficiency. This behavior was also found for encapsulated oils like andiroba oil (Senhorini et al., 2012), chia seeds oil (Inácio et al., 2018) as well as other hydrophobic substances (Özdemir \& Gökmen, 2015).

Characteristic absorption bands of $\mathrm{C}=\mathrm{C}-\mathrm{H}$ and $\mathrm{C}=\mathrm{O}$ of the oils were found at 3010 and $1740 \mathrm{~cm}^{-1}$, respectively. These bands may be attributed to chain unsaturation in the FA and to carbonyl groups of the ester groups of triacylglycerol structures (Freiberger et al., 2015; Vidal et al., 2014). The band at $3010 \mathrm{~cm}^{-1}$ was intense in the pure oils but it was attenuated in the oil-loaded microparticles. The decrease in intensity was greater than expected if only caused by the low concentration of oils in the microparticles, being also related with the saturated nature of the shell material used (stearic acid), consistent with the effective entrapment of the oils inside the microparticles. The higher attenuation observed with green coffee oil, compared to walnut oil, is consistent with the encapsulation efficiency (Table 2).

\subsection{Thermal stability}

Fig. 2 shows the non-isothermal DSC curves for the oils (green coffee and walnut) and for the oil-loaded microparticles (regression curves are shown in Fig. S4, Supplementary Material).

Activation energy values found for green coffee oil and the corresponding oil-loaded microparticles were $82 \pm 4$ and $1.05 \pm 0.0910 \mathrm{~kJ}$ $\mathrm{mol}^{-1}$, respectively, and for walnut oil and the corresponding oil-loaded microparticles were $90 \pm 5$ and $149 \pm 1 \mathrm{~kJ} \mathrm{~mol}^{-1}$, respectively. Lipid oxidative degradation is initiated by a free radical with the formation of radicals occurring throughout the reaction. Oil oxidation is usually evaluated using the kinetic parameters at the beginning of the reaction (Micić et al., 2015) where higher activation energy denotes an increased stability. Lipid degradation is complex due to the presence of primary reaction products such as hydroperoxides, which increases degradation rates at low temperatures, but also because intermediary products such as aldehydes and acids may evaporate when temperature increases (Micić et al., 2015). Oxidation onset temperatures increased as expected for all samples whilst it was higher for the oil-loaded microparticles 


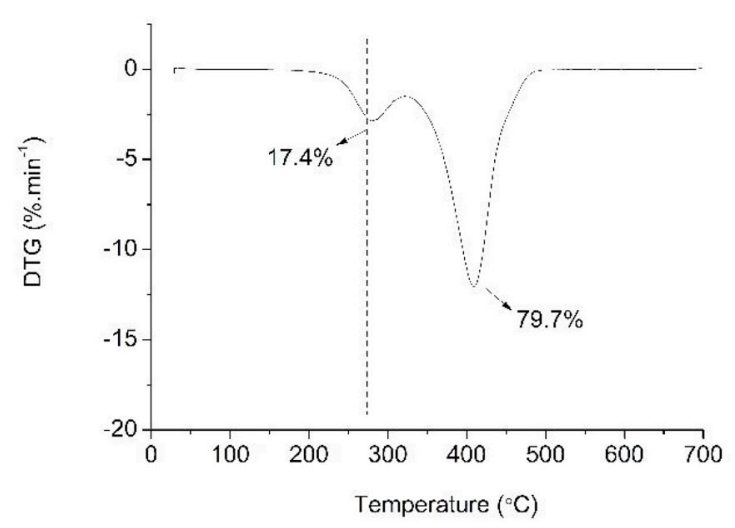

(a)

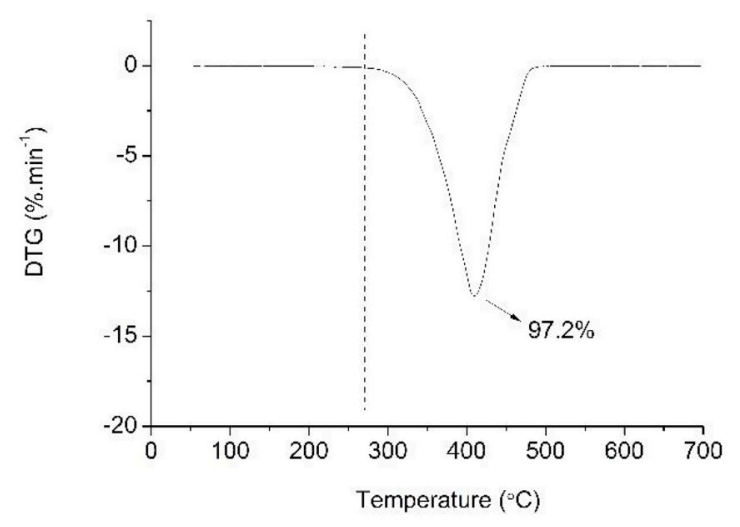

(c)

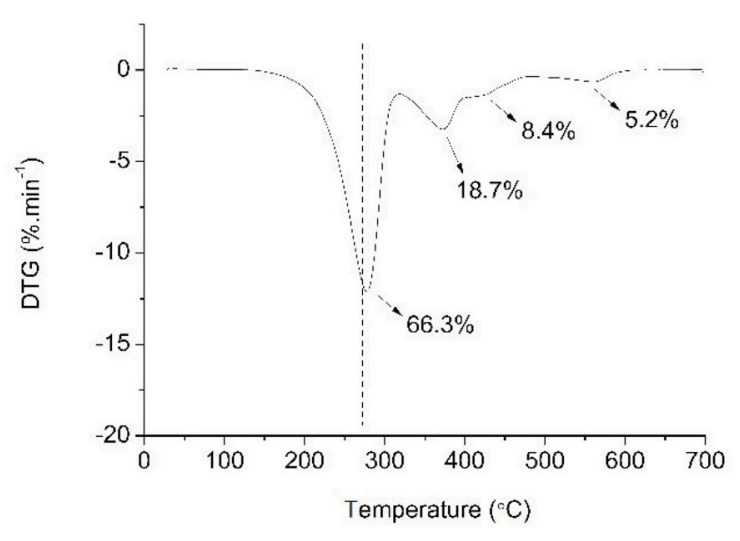

(b)

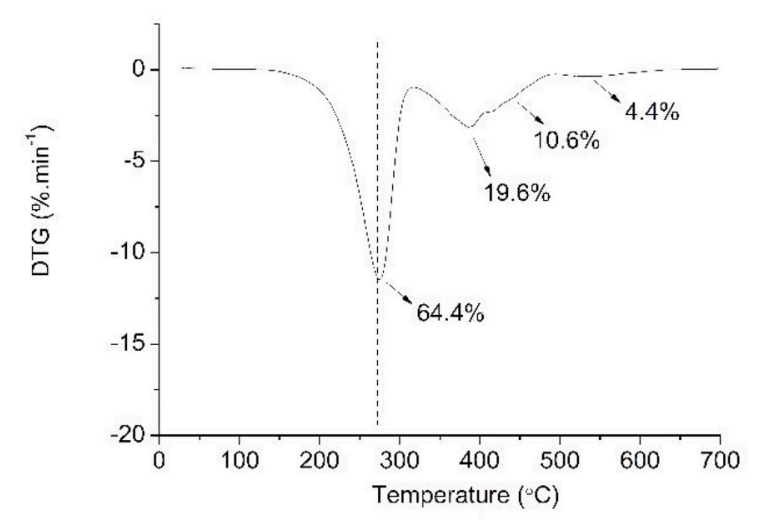

(d)

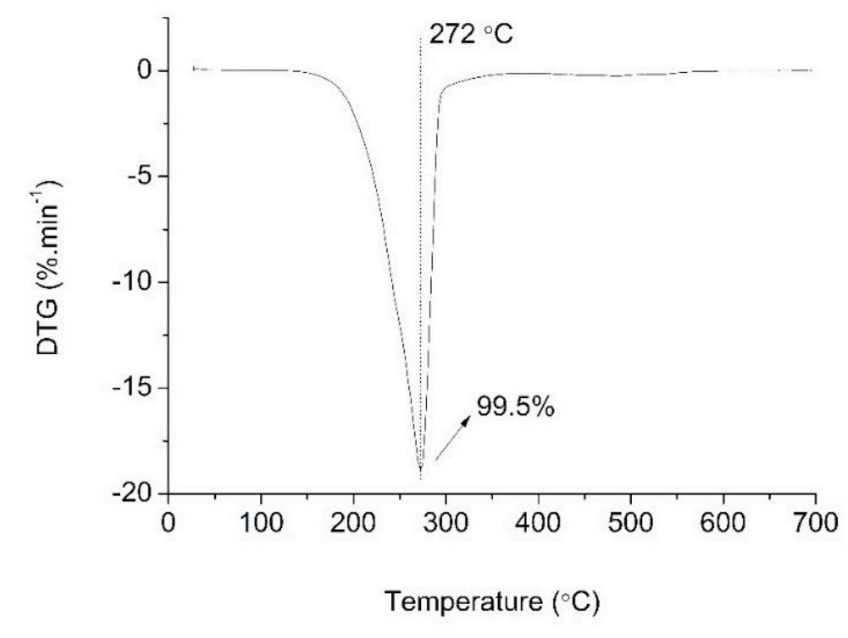

(e)

Fig. 3. Differential thermogravimetric analyses curves for free and encapsulated oils: (a, b) Green coffee; (c, d) Walnut; and (e) Blank microparticles (no oil added). Dotted lines indicate the temperature of maximum weight loss of the encapsulant. (e) Blank microparticles (no oil added). (a) Green coffee oil. (b) Green coffee-oil loaded microparticles (c) Walnut oil. (d) Walnut oil-loaded microparticles. (e) Blank microparticles (no oil added). 


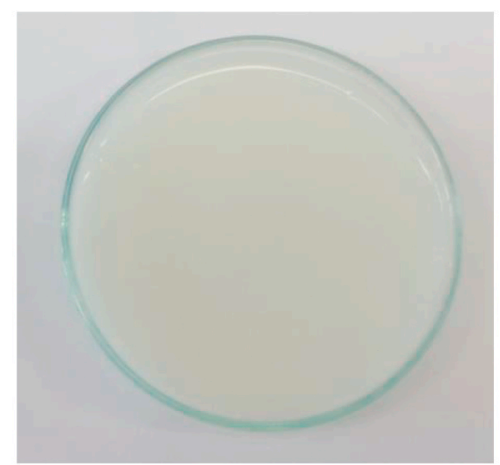

(a)

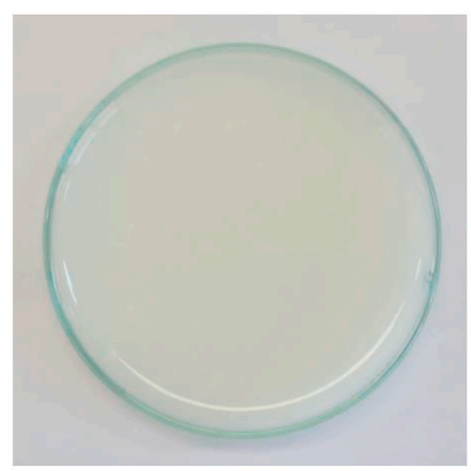

(b)

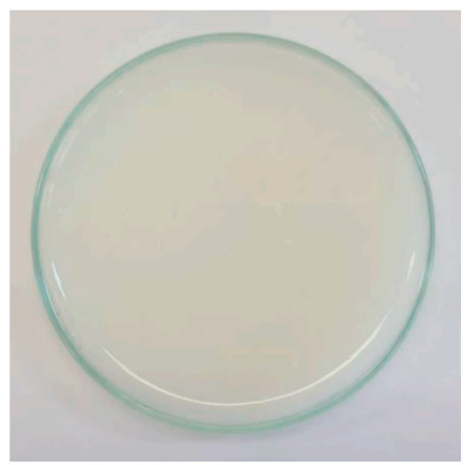

(e)

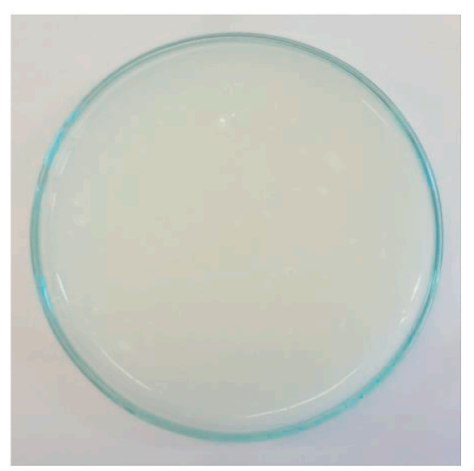

(c)

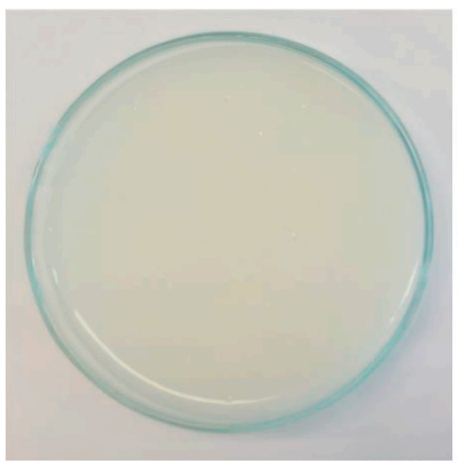

(f)

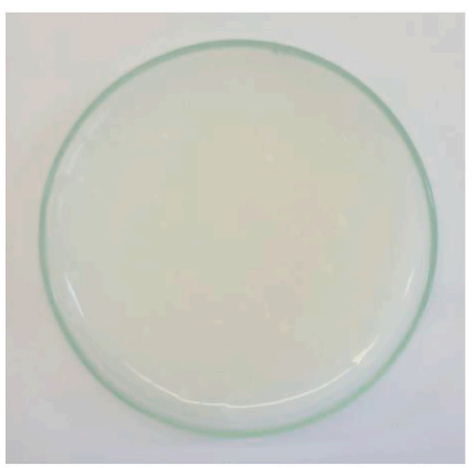

(d)

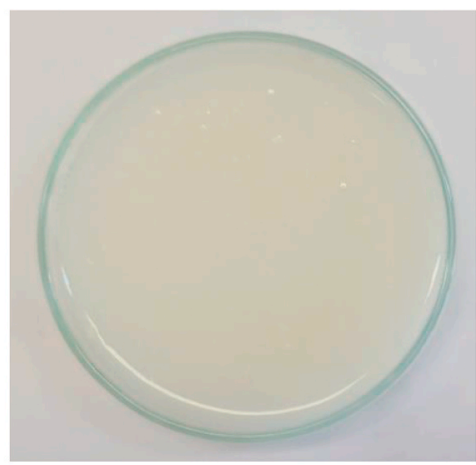

(g)

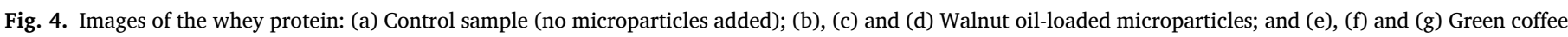

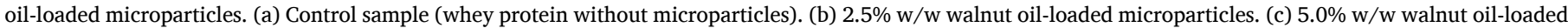

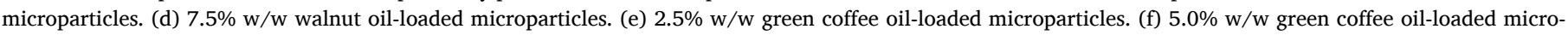

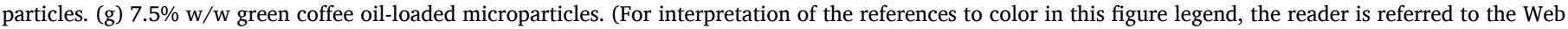
version of this article.)

when compared with the corresponding free oils at the same heating rate. Moreover, activation energy was higher for the microencapsulated oil with a significant improvement for walnut oil. This is an improvement of the oil stability which was previously reported for other oils and encapsulants (Grampone et al., 2013; Inácio et al., 2018).

Differential TGA (DTGA) curves of the oils, oil-loaded microparticles and blank microparticles (no oil added) are shown in Fig. 3. DTGA curves of the walnut oil showed that weight loss occurred at $\sim 410{ }^{\circ} \mathrm{C}$ (97.2\% weight loss) while for coffee oil weight loss was found at $278{ }^{\circ} \mathrm{C}$ (17.4\%) and thereafter at $410{ }^{\circ} \mathrm{C}(79.7 \%)$. This difference may be attributed to the higher concentration of low molar mass FA (mainly palmitic acid) in green coffee oil, when compared to walnut oil. The encapsulant (stearic acid) showed the maximum weight loss at $272{ }^{\circ} \mathrm{C}$ (17.4\%). This peak was also observed in the microparticles as expected.

Results showed that the oils were successfully encapsulated and their oxidative stability was improved due to encapsulation. This means that the microparticles may successfully protect the oils in the preparation of enriched foods.

\subsection{Whey protein supplement containing the microparticles}

Nutritional composition of the whey protein before the addition of 


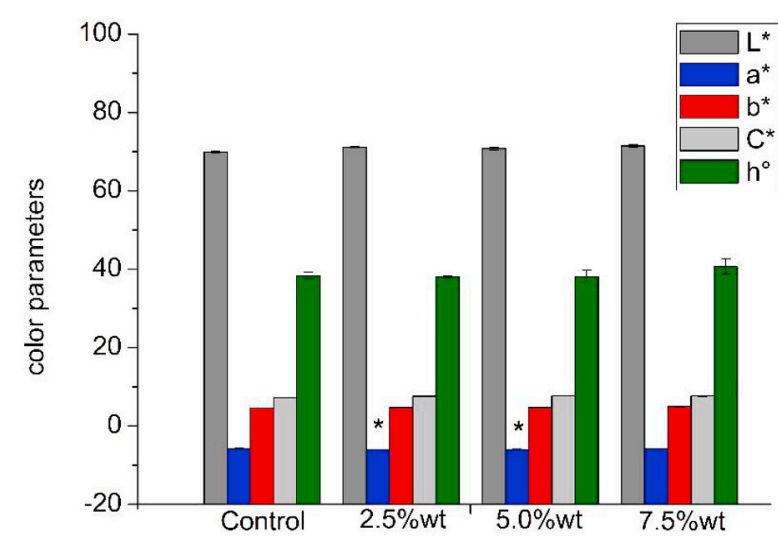

(a)

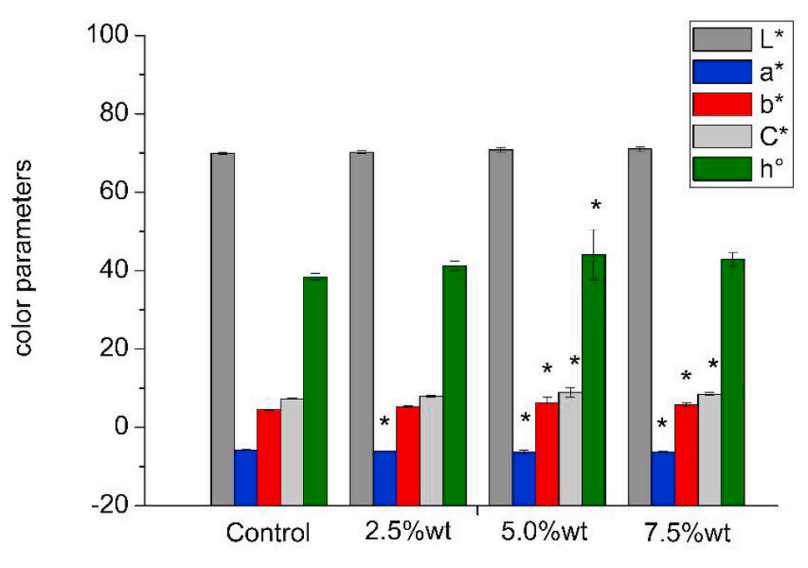

(b)

Fig. 5. Color parameters of the whey protein containing $0 \% \mathrm{w} / \mathrm{w}$ (control sample) $2.5 \% \mathrm{w} / \mathrm{w}, 5.0 \% \mathrm{w} / \mathrm{w}$ and $7.5 \% \mathrm{w} / \mathrm{w}$ of oil-loaded microparticles (units for $L^{*}, a^{*}, b^{*} C^{*}$ are arbitrary and unit for $h^{\circ}$ is degree). (a) Whey protein containing walnut oil-loaded microparticles. (b) Whey protein containing green coffee oil-loaded microparticles. Results were compared using Tukey test with $5 \%$ significance. (For interpretation of the references to color in this figure legend, the reader is referred to the Web version of this article.)

the microparticles was determined as follows: $4.58 \pm 0.03 \%$ humidity, $1.09 \pm 0.02 \%$ ash, $77.5 \pm 0.1 \%$ crude proteins, $3.0 \pm 0.1 \%$ total lipids, $13.9 \pm 0.1 \%$ carbohydrates (by difference). These values are consistent with the nutritional data provided on the product label.

Microparticles were added to the whey protein and then the final product dispersed in water as recommended by the manufacturer for the whey supplement. Images of the whey protein containing the green coffee and walnut oil-loaded microparticles are shown in Fig. 4 showing the general aspect of the supplements. Fig. 5 shows the color parameters determined for each formulation.

High luminosity, low yellow $\left(+\mathrm{b}^{*}\right)$ and green $(-\mathrm{a})$, and low color intensity $\left(C^{*}\right)$ were found for all samples. WPS with 2.5 and $5.0 \% \mathrm{w} / \mathrm{w}$ of walnut oil-loaded microparticles showed the $a$ parameter statistically different from control samples ( $\mathrm{p} \geq 0.05$ ) while no difference was found for the $7.5 \% \mathrm{w} / \mathrm{w}$. This difference was not observed visually by the authors (Fig. 4). For the green coffee oil, statistically significant differences were found for particles concentrations of 5.0 and $7.5 \% \mathrm{w} / \mathrm{w}$ meaning that these concentrations influenced the color of the whey protein supplement. Although images in Fig. 4 do not provide enough visual contrast, it was possible to observe this difference visually by the authors in the original samples.

Rheology curves were obtained at 25 and $37{ }^{\circ} \mathrm{C}$ for the whey protein containing the oil-loaded microparticles and then fit to the mathematical models of Casson, Binghan and Hurschel-Bulkley. These results are shown in Table S1 and Figs. S5 and S6 (Supplementary Material).

The whey protein supplement (base product and product with oilloaded microparticles) showed non-Newtonian, pseudoplastic behavior, and thixotropic flow with small hysteresis for all samples. The Herschel-Bulkley model showed the best correlation coefficient and the smaller error thus being the most suitable model to represent the data for both temperatures. The supplement was highly fluid in all cases with low shear stress (all samples were below 4.0 Pa). This is expected because whey proteins were not gelatinized in this type of supplement (Kilara and Vanghela, 2004). The samples analyzed at $25{ }^{\circ} \mathrm{C}$ showed a shear stress higher than $37{ }^{\circ} \mathrm{C}$ samples, when compared at the same strain rate (Fig. S5) which was expected (Tabilo-Munizaga \& Barbosa-Cánovas, 2005). As observed in Figs. S5 and S6, the curves coincide with each other, indicating a similar rheological behavior between the samples, which was also confirmed by the results shown in Table S1. Parameters $K_{\mathfrak{c}}, \eta_{\mathrm{a}}$ and $\mathrm{K}$ (Table S1) were also representative of low viscosity systems. Low viscosity and non-Newtonian flow were also observed for partially denaturated whey protein (Zhang et al., 2016). The samples parameters did not show a definite tendency related to the increase of the concentration of microparticles. To understand this behavior, a comparative analysis was done between the averages using the Tukey test and no significant difference $(\mathrm{p}<0.05)$ of the microparticles' addition to the whey supplement was found for both encapsulated oils. Due to the similarity of the results, the rheological analysis indicated that the oil-loaded microparticles probably did not alter the three-dimensional structure of the protein and did not promote thermodynamic incompatibility.

There was no significant difference $(\mathrm{p}<0.05)$ between the preference for the whey protein samples enriched or not with walnut oil microparticles. Thus, it is possible to add up to $5 \% \mathrm{w} / \mathrm{w}$ of walnut oil microparticles in whey protein based beverages, without affecting the preference of the samples and obtaining the nutritional gain resulting from this addition. It was determined that the addition of green coffee microparticles had a negative impact on the preference of the whey protein beverages. The most preferred was the beverage without enrichment, while the least preferred sample was the beverage with $5 \%$ $\mathrm{w} / \mathrm{w}$ of green coffee oil microparticles.

Several factors can cause the reduction of food preference such as changes in appearance, taste or other sensory characteristics. As the preference ranking test is a non-specific test, it is not possible to state which factor promoted the preference reduction. It is suggested that the color change caused by the addition of the microparticles of green coffee oil, as shown by the colorimetric analysis, may be responsible for this preference decrease. Research evaluating additions of green coffee extract in soymilk (Sęczyk et al., 2017) and ground green coffee beans in breads (Zain et al., 2018) found that color is the sensorial attribute whose acceptance is negatively influenced by the addition.

\section{Conclusion}

Whey protein supplements containing oil-loaded microparticles were produced using walnut oil or green coffee oil. Encapsulation resulted in an efficient protection of the oils against oxidative degradation as determined using DSC and TGA. High encapsulation efficiencies were found using GC and further confirmed using spectroscopic and thermic characterization. The main FA present in walnut oil were linoleic acid and $\alpha$-linolenic acids, while linoleic and palmitic acids were predominant in green coffee oil. This last oil also showed more tocopherols with the prevalence of $\alpha$ - and $\beta$-tocopherols. 
Concentrations of 2.5, 5.0 and $7.5 \%$ of oil-loaded microparticles were added to the whey protein supplement. Rheology analysis showed that the microparticles did not influence flow behavior or viscosity, which is important from a commercial point of view. For the walnut oil microparticles, no appreciable change in color was found, even when $7.5 \%$ of microparticles were added. However, for the green coffee oil microparticles at this concentration changed the color of the supplement. Sensory analysis was carried out to determine if consumer's preference would be influenced by the presence of the microparticles at 2.5 and $5.0 \%$, it being concluded that it was not affected when walnut oil microparticles were added, for all the tested concentrations, but decreased when green coffee oil-loaded microparticles were used, particularly at $7.5 \%$.

Results showed that it is feasible to produce a whey protein supplement enriched with microencapsulated polyunsaturated FA, which might be an interesting ingredient.

\section{Declaration of competing interest}

The authors declare that they have no known competing financial interests or personal relationships that could have appeared to influence the work reported in this paper.

\section{CRediT authorship contribution statement}

Valquíria Maeda Rojas: Methodology, Investigation, Writing original draft. Alexandre Guimarães Inácio: Methodology, Investigation, Writing - original draft. Isabel Patricia Martins Fernandes: Methodology, Writing - original draft. Fernanda Vitória Leimann: Conceptualization, Methodology, Writing - original draft, Writing - review \& editing. Angela Maria Gozzo: Conceptualization, Writing original draft. Renata Hernandez Barros Fuchs: Conceptualization, Methodology, Writing - original draft. Maria Filomena Filipe Barreiro: Methodology, Writing - original draft. Lillian Barros: Methodology, Writing - original draft. Isabel C.F.R. Ferreira: Methodology, Writing original draft, Writing - review \& editing. Ailey Aparecida Coelho Tanamati: Conceptualization, Methodology, Writing - original draft. Odinei Hess Gonçalves: Conceptualization, Methodology, Writing original draft, Writing - review \& editing.

\section{Acknowledgements}

This study was financed in part by the Coordenação de Aperfeiçoamento de Pessoal de Nível Superior - Brasil (CAPES) - Finance Code 001. This work was financially supported by Associate Laboratory LSRE-LCM (UIDB/50020/2020) and CIMO (UIDB/00690/2020) funded by national funds through FCT/MCTES.

\section{Appendix A. Supplementary data}

Supplementary data to this article can be found online at https://doi. org/10.1016/j.fbio.2020.100690.

\section{References}

Abnt. (2015). Nbr ISO 8587: Sensory analysis - methodology - ranking. Rio de Janeiro: Brazilian Association of Technical Norms. NBR ISO 8587: Análise Sensorial, Metodologia, Ordenação, Rio de Janeiro: Associação Brasileira de Normas Técnicas.

Adhvaryu, A., Erhan, S. Z., Liu, Z. S., \& Perez, J. M. (2000). Oxidation kinetic studies of oils derived from unmodified and genetically modified vegetables using pressurized differential scanning calorimetry and nuclear magnetic resonance spectroscopy. Thermochimica Acta, 364(1-2), 87-97. https://doi.org/10.1016/S0040-6031(00) 00626-2.

Adolfo Lutz Institute. (2008). Physicochemical methods for food analysis (p. 1020). São Paulo, Brazil: Adolfo Lutz Institute. Instituto Adolfo Lutz. (2008). Physicochemical Methods for Food Analysis (pp. 1020). São Paulo, Brazil: Instituto Adolfo Lutz.

Albertini, B., Passerini, N., Pattarino, F., \& Rodriguez, L. (2008). New spray congealing atomizer for the microencapsulation of highly concentrated solid and liquid substances. European Journal of Pharmaceutics and Biopharmaceutics, 69(1), 348-357. https://doi.org/10.1016/j.ejpb.2007.09.011.

Altunkaya, A., Hedegaard, R. V., Harholt, J., Brimer, L., Gökmen, V., \& Skibsted, L. H. (2013). Oxidative stability and chemical safety of mayonnaise enriched with grape seed extract. Food \& Function, 4(11), 1647-1653. https://doi.org/10.1039/ c3fo60204d.

Barros, L., Pereira, E., Calhelha, R. C., Dueñas, M., Carvalho, A. M., Santos-Buelga, C., \& Ferreira, I. C. F. R. (2013). Bioactivity and chemical characterization in hydrophilic and lipophilic compounds of Chenopodium ambrosioides L. Journal of Functional Foods, 5(4), 1732-1740. https://doi.org/10.1016/j.jff.2013.07.019.

Bertrand, B., Villarreal, D., Laffargue, A., Posada, H., Lashermes, P., \& Dussert, S. (2008). Comparison of the effectiveness of FA, chlorogenic acids, and elements for the chemometric discrimination of coffee (Coffea arabica L.) varieties and growing origins. Journal of Agricultural and Food Chemistry, 56(6), 2273-2280. https://doi. org/10.1021/jf073314f.

Bresciani, L., Calani, L., Bruni, R., Brighenti, F., \& Del Rio, D. (2014). Phenolic composition, caffeine content and antioxidant capacity of coffee silverskin. Food Research International, 61, 196-201. https://doi.org/10.1016/j.foodres.2013.10.047.

Budryn, G., Nebesny, E., Zyzelewicz, D., Oracz, J., Miśkiewicz, K., \& RosickaKaczmarek, J. (2012). Influence of roasting conditions on FA and oxidative changes of Robusta coffee oil. European Journal of Lipid Science and Technology, 114(9), 1052-1061. https://doi.org/10.1002/ejlt.201100324.

Calvo, P., Castaño, Á. L., Hernández, M. T., \& González-Gómez, D. (2011). Effects of microcapsule constitution on the quality of microencapsulated walnut oil. European Journal of Lipid Science and Technology, 113(10), 1273-1280. https://doi.org/ 10.1002/ejlt.201100039.

Chivero, P., Gohtani, S., Yoshii, H., \& Nakamura, A. (2016). Assessment of soy soluble polysaccharide, gum Arabic and OSA-Starch as emulsifiers for mayonnaise-like emulsions. Lebensmittel-Wissenschaft und -Technologie- Food Science and Technology, 69, 59-66. https://doi.org/10.1016/j.lwt.2015.12.064.

Christopoulos, M. V., \& Tsantili, E. (2015). Oil composition in stored walnut cultivars quality and nutritional value. European Journal of Lipid Science and Technology, 117 (3), 338-348. https://doi.org/10.1002/ejlt.201400082.

Ciftci, O. N., \& Temelli, F. (2016). Formation of solid lipid microparticles from fully hydrogenated canola oil using supercritical carbon dioxide. Journal of Food Engineering, 178, 137-144. https://doi.org/10.1016/j.jfoodeng.2016.01.014.

Ciprioti, S. V., Paciulli, M., \& Chiavaro, E. (2017). Application of different thermal analysis techniques to characterize oxidized olive oils. European Journal of Lipid Science and Technology, 119(1), 1600074. https://doi.org/10.1002/ejlt.201600074.

Đorđević, V., Balanč, B., Belščak-Cvitanović, A., Lević, S., Trifković, K., Kalušević, A., Kostić, I., Komes, D., Bugarski, B., \& Nedović, V. (2015). Trends in encapsulation technologies for delivery of food bioactive compounds. Food Engineering Reviews, 7, 452-490. https://doi.org/10.1007/s12393-014-9106-7.

Flynn, J. H., \& Wall, L. A. (1966). A quick, direct method for the determination of activation energy from thermogravimetric data. Journal of Polymer Science - Part B: Polymer Letters, 4(5), 323-328. https://doi.org/10.1002/pol.1966.110040504.

Freiberger, E. B., Kaufmann, K. C., Bona, E., Hermes de Araújo, P. H., Sayer, C., Leimann, F. V., \& Gonçalves, O. H. (2015). Encapsulation of roasted coffee oil in biocompatible nanoparticles. Lebensmittel-Wissenschaft und -Technologie- Food Science and Technology, 64(1), 381-389. https://doi.org/10.1016/j.lwt.2015.05.039.

Fuchs, R. H. B., Ribeiro, R. P., Matsushita, M., Tanamati, A. A. C., Bona, E., \& de Souza, A. H. P. (2013). Enhancement of the nutritional status of Nile tilapia (Oreochromis niloticus) croquettes by adding flaxseed flour. LebensmittelWissenschaft und -Technologie- Food Science and Technology, 54(2), 440-446. https:// doi.org/10.1016/j.lwt.2013.07.004.

Garrido, B. C., Souza, G. H. M. F., Lourenço, D. C., \& Fasciotti, M. (2016). Proteomics in quality control: Whey protein-based supplements. Journal of Proteomics, 147, 48-55. https://doi.org/10.1016/j.jprot.2016.03.044.

Getachew, A. T., \& Chun, B. S. (2016). Optimization of coffee oil flavor encapsulation using response surface methodology. Lebensmittel-Wissenschaft und-Technologie- Food Science and Technology, 70, 126-134. https://doi.org/10.1016/j.lwt.2016.02.025.

González, A. G., Pablos, F., Martín, M. J., León-Camacho, M., \& Valdenebro, M. S. (2001). HPLC analysis of tocopherols and triglycerides in coffee and their use as authentication parameters. Food Chemistry, 73(1), 93-101. https://doi.org/10.1016/ S0308-8146(00)00282-X.

Grampone, M. A., Irigaray, B., Rodríguez, D., \& Sammán, N. (2013). Assessing the oxidative stability of commercial chia oil. Journal of Food Science and Engineering, 3, 349-356.

Groziak, S. M., \& Miller, G. D. (2000). Natural bioactive substances in milk and colostrum: Effects on the arterial blood pressure system. British Journal of Nutrition, 84, S119-S125. https://doi.org/10.1017/S0007114500002348.

Inácio, G. A., Francisco, C. R. L., Rojas, V. M., Leone, R. S., Valderrama, P., Bona, E., Leimann, F. V., Tanamati, A. A. C., \& Gonçalves, O. H. (2018). Evaluation of the oxidative stability of chia oil-loaded microparticles by thermal, spectroscopic and chemometric methods. Lebensmittel-Wissenschaft und-Technologie-Food Science and Technology, 87, 498-506. https://doi.org/10.1016/j.lwt.2017.09.031.

Ixtaina, V. Y., Mattea, F., Cardarelli, D. A., Mattea, M. A., Nolasco, S. M., \& Tomas, M. C. (2011). Supercritical carbon dioxide extraction and characterization of Argentinean chia seed oil. Journal of the American Oil Chemists Society, 88(2), 289-298. https:// doi.org/10.1007/s11746-010-1670-2.

Kilara, A., \& Vaghela, M. N. (2004). Whey proteins. In R. Y. Yada (Ed.), Proteins in food processing (pp. 72-99). Cambridge, England: CRC Press.

Lancaster, J. E., \& Lister, C. E. (1997). Influence of pigment composition on skin color in a wide range of fruit and vegetables. Journal of the American Society for Horticultural Science, 4, 594-598. 
Lemes, G. F., Marchiore, N. G., Moreira, T. F. M., Silva, T. B. V., Sayer, C., Shirai, M. A., Gonçalves, O. H., Gozzo, A. M., \& Leimann, F. V. (2017). Enzymatically crosslinked gelatin coating added of bioactive nanoparticles and antifungal agent: Effect on the quality of Benitaka grapes. Lebensmittel-Wissenschaft und -Technologie- Food Science and Technology, 84, 175-182. https://doi.org/10.1016/j.lwt.2017.05.050.

Martínez, M., Barrionuevo, G., Nepote, V., Grosso, N., \& Maestri, D. (2011). Sensory characterisation and oxidative stability of walnut oil. International Journal of Food Science and Technology, 46(6), 1276-1281. https://doi.org/10.1111/j.13652621.2011.02618.x.

Mexis, S. F., Badeka, A. V., Riganakos, K. A., Karakostas, K. X., \& Kontominas, M. G. (2009). Effect of packaging and storage conditions on quality of shelled walnuts. Food Control, 20(8), 743-751. https://doi.org/10.1016/j.foodcont.2008.09.022.

Micić, D. M., Ostojić, S. B., Simonović, M. B., Krstić, G., Pezo, L. L., \& Simonović, B. R. (2015). Kinetics of blackberry and raspberry seed oils oxidation by DSC. Thermochimica Acta, 601, 39-44. https://doi.org/10.1016/j.tca.2014.12.018.

Ostrowska-Ligeza, E., Bekas, W., Kowalska, D., Lobacz, M., Wroniak, M., \& Kowalski, B. (2010). Kinetics of commercial olive oil oxidation: Dynamic differential scanning calorimetry and Rancimat studies. European Journal of Lipid Science and Technology, 112(2), 268-274. https://doi.org/10.1002/ejlt.200900064.

Ozawa, T. (1970). Kinetic analysis of derivate curves in thermal analysis. Journal of Thermal Analyses, 2, 301-324.

Özdemir, K. S., \& Gökmen, V. (2015). Effect of microencapsulation on the reactivity of ascorbic acid, sodium chloride and vanillin during heating. Journal of Food Engineering, 167, 204-209. https://doi.org/10.1016/j.jfoodeng.2015.03.029.

Rojas, V. M., Marconi, L. F., da, C. B., Inácio, G. A., Leimann, F. V., Tanamati, A., Gozzo, Â. M., Fuchs, R. H. B., \& Gonçalves, O. H. (2019). Formulation of mayonnaises containing PUFAs by the addition of microencapsulated chia seeds, pumpkin seeds and baru oils. Food Chemistry, 274(August 2018), 220-227. https:// doi.org/10.1016/j.foodchem.2018.09.015.
Sęczyk, Ł., Świeca, M., \& Gawlik-Dziki, U. (2017). Soymilk enriched with green coffee phenolics - antioxidant and nutritional properties in the light of phenolics-food matrix interactions. Food Chemistry, 223, 1-7. https://doi.org/10.1016/j. foodchem.2016.12.020.

Senhorini, G. A., Zawadzki, S. F., Farago, P. V., Zanin, S. M. W., \& Marques, F. A. (2012). Microparticles of poly (hydroxybutyrate- co -hydroxyvalerate) loaded with andiroba oil: Preparation and characterization. Materials Science and Engineering: C, 32(5), 1121-1126. https://doi.org/10.1016/j.msec.2012.02.027.

Tabilo-Munizaga, G., \& Barbosa-Cánovas, G. V. (2005). Rheology for the food industry. Journal of Food Engineering, 67(1-2), 147-156. https://doi.org/10.1016/j. jfoodeng.2004.05.062.

Ulkowski, M., Musialik, M., \& Litwinienko, G. (2005). Use of differential scanning calorimetry to study lipid oxidation. 1. Oxidative stability of lecithin and linolenic acid. Journal of Agricultural and Food Chemistry, 53(23), 9073-9077. https://doi.org/ 10.1021/jf051289c.

Uzunova, G., Perifanova-Nemska, M., Stojanova, M., \& Gandev, S. (2015). Chemical composition of walnut oil from fruits on different years old branches. Bulgarian Journal of Agricultural Science, 21(3), 494-497.

Vidal, N. P., Goicoechea, E., Manzanos, M. J., \& Guillén, M. D. (2014). Fourier transform infrared spectroscopy as a tool to study farmed and wild sea bass lipid composition. Journal of the Science of Food and Agriculture, 94(7), 1340-1348. https://doi.org/ $10.1002 /$ jsfa.6417.

Zain, M. Z. M., Baba, A. S., \& Shori, A. B. (2018). Effect of polyphenols enriched from green coffee bean on antioxidant activity and sensory evaluation of bread. Journal of King Saud University Science, 30(2), 278-282. https://doi.org/10.1016/j. jksus.2017.12.003.

Zhang, Z., Arrighi, V., Campbell, L., Lonchamp, J., \& Euston, S. R. (2016). Properties of partially denatured whey protein products 2 : Solution flow properties. Food Hydrocolloids, 56, 218-226. https://doi.org/10.1016/j.foodhyd.2015.12.012. 